\title{
Hiperbarik oksijen tedavisi
}

\section{Hyperbaric oxygen therapy}

\author{
Fırat Ozan ${ }^{1}$, Taşkın Altay², Cemil Kayalı²
}

\begin{abstract}
${ }^{1}$ Kayseri Eğitim ve Araştırma Hastanesi, Ortopedi ve Travmatoloji Kliniği, Kayseri, Türkiye ${ }^{2}$ İzmir Bozyaka Eğitim ve Araştırma Hastanesi, Ortopedi ve Travmatoloji Kliniği, İzmir, Türkiye
\end{abstract}

\begin{abstract}
Hiperbarik oksijen (HBO) tedavisi veya hiperoksijenasyon, medikal bir durumu tedavi etmek için yüksek basınçlı bir ortamda \%100 oksijen uygulanmasına yönelik bir tedavi yöntemidir. HBO tedavisinin modern klinik uygulaması, kan gazı analizi ve gaz değişimi fizyolojisinin daha iyi anlaşılmasına paralel olarak başlamış ve gelişmiştir. HBO tedavisinin insan vücudu üzerinde iki temel fizyolojik etkisi vardır. Bunlardan biri vücut içindeki gazlar üzerine mekanik, diğeri ise kanda parsiyel oksijen basıncını arttırıcı etkisidir. Günümüzde HBO tedavisinin etkilerinin daha iyi anlaşılması ile ortopedi ve travmatoloji alanındaki; diyabetik yaralar, problemli yaralar, nekrotizan yumuşak doku enfeksiyonları, kronik osteomiyelit, sorunlu deri flep ve greftleri, bazı akut iskemik durumlar, gazlı gangren gibi patolojiler $\mathrm{HBO}$ tedavisinin yaygın endikasyon alanına girmiş ve etkin bir tedavi yöntemi olarak kullanılmaktadır. Diğer yandan, spor yaralanmaları, kapalı yumuşak doku yaralanmaları, kırık iyileşmesi, osteonekroz, omurilik yaralanmaları, periferik sinir yaralanmaları gibi patolojilerde ise HBO tedavisi sonucuna ilişkin olumlu raporlar olmakla birlikte, tedavi etkinliğine yönelik kanıt değeri daha yüksek çalışmalara ihtiyaç duyulmaktadır.
\end{abstract}

Anahtar sözcükler: hiperbarik oksijen tedavisi; fizyopatoloji; ortopedik uygulamalar
Hyperbaric oxygen (HBO) therapy or hyperoxygenation is a treatment method which may be defined as applying $100 \%$ oxygen in a high-pressure environment to treat a medical case. The modern clinical practice of $\mathrm{HBO}$ therapy has begun and developed parallel to the increased understanding of physiology of blood gas analysis and gas exchange. There are two basic physiological effects of HBO therapy on the human body: the first is the mechanical effect on the gases in the body and the other is the enhancing of partial oxygen pressure. Nowadays, with a better under-standing of the effects of HBO therapy, it can be used in orthopedics and traumatology as an effective treatment method with common indications in pathologies such as diabetic injuries, problematic injuries, necrotizing soft tissue infections, chronic osteomyelitis, problematic skin flaps and grafts, some acute ischemic conditions, and gas gangrene. On the other hand, there is a need for higher evidence of treatment efficacy in spite of positive reports on $\mathrm{HBO}$ treatment outcome in pathologies such as sports injuries, closed soft tissue injuries, fracture healing, osteone-crosis, spinal cord injuries, peripheral nerve injuries.

Key words: hyperbaric oxygen therapy; physiopathology; orthopedic practices

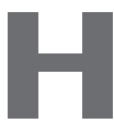

iperbarik oksijen (HBO) tedavisi, hastalığı tedavi etmek amaçlı kapalı bir sistem içinde, deniz seviyesindeki atmosferik basınçtan daha yüksek bir basınçta, maske, başılı veya ortamdan sürekli ya da aralıklı \%100 oksijen solutulması ile uygulanan bir tedavi şeklidir. ${ }^{[1-4]}$ Deniz seviyesindeki atmosfer basıncı 1 ATA'dır (1 ATA, atmosphere absolute $=760$ $\mathrm{mmHg}$ ); deniz seviyesinden $10 \mathrm{~m}$ derinlikte 2 ATA; ve $20 \mathrm{~m}$ derinlikte ise 3 ATA'dır. ${ }^{[1,2]}$

Oksijen, 17. yüzyılın sonlarında Joseph Priestley tarafından keşfedilmiştir. ${ }^{[3,5]}$ Hiperbarik oksijen tedavisinin modern klinik uygulaması, kan gazı analizi ve gaz değişimi fizyolojisinin artan anlayışına paralel olarak, 1950'lerin sonlarında başlamıştır. ${ }^{[3,5-7]} 1970$ 'lerin sonunda ise Denizaltı ve Hiperbarik Tıp Birliği (Undersea and Hyperbaric Medical Society, UHMS), HBO tedavisinin temel kural ve prensiplerini yayımlanmıştır. ${ }^{[2,3,5,6]}$ UHMS tarafindan 2-3 yılda bir yapılan uluslararası toplantılarla, günümüzde HBO tedavisinin esasları, yeni gelişmeler ve uygulamaları yayımlanmaktadır. ${ }^{[3,7]}$

HBO tedavisinin iyileştirici etkileri, doku oksijen dağıtımındaki plazmada çözünmüş oksijenin seviyesinin

- İletişim adresi: Doç. Dr. Taşkın Altay, İzmir Bozyaka Eğitim ve Araştırma Hastanesi, Ortopedi ve Travmatoloji Kliniği, Saim Çıkrıkçı Cad. No: 59, Bozyaka, İzmir, Türkiye Tel: 0232 - 2505050 e-posta: taskinaltay@yahoo.com

- Geliș tarihi: 20 Mart $2017 \quad$ Kabul tarihi: 20 Mart 2017 
yükselmesinin sonucudur. ${ }^{[8]}$ HBO tedavisi, tek kişilik veya çok kişilik hiperbarik odaları kullanılarak gerçekleştirilmekte, lokal olarak da uygulanabilmektedir. ${ }^{[1,3,5]}$

HBO tedavisinin vücut üzerindeki etkileri, birincil ve ikincil etkiler olarak ikiye ayrılabilir. Birincil etkiler dokunun aşırı oksijenasyonunu içerir; ezilme yaralanması, kompartman sendromu, sorunlu cilt grefti veya flep olguları ile gazlar üzerindeki mekanik etki ile hava embolisi olgularında etkili bir şekilde kullanılabilmektedir. ${ }^{[1,3,5,8]}$ HBO tedavisinin sekonder etkileri ise vazokonstriksiyon, anjiyogenez, fibroblast proliferasyonu, kollajen sentezi artışı ve artmış lökosit oksidatif öldürme fonksiyonunu içerir. ${ }^{[1,3,5,8]}$

Hiperbarik oksijen tedavisinin temeli, hiperoksinin fizyolojik, biyokimyasal etkilerine ve gaz kanunlarına dayanır ${ }^{[9]}$ :

Boyle-Mariotte yasasına göre, bir gazın hacmi ve basıncı, sabit bir ısıda birbiriyle ters orantılıdır. Diğer bir deyişle, belirli bir ısıdaki gazın basıncı ile hacminin çarpımı daima sabittir (gazın birinci denge hali için basıncı P1, hacmi V1; ikinci denge hali için basıncı P2, hacmi V2):

$$
P_{1} \times V_{1}=P_{2} \times V_{2}
$$

Dalton yasası, bir karışım içerisinde bulunan her gaz, karışım içerisindeki miktarı oranında bir basınç meydana getirir ( $\mathrm{P}$, gaz basıncı):

$$
P_{\text {total }}=P_{1}+P_{2}+P_{3}+\ldots+P_{n}
$$

Henry yasası, sabit bir ısıda bir sıvı içinde ya da dokuda çözünmüş olan gaz miktarının, sıvının ya da dokunun temasta olduğu gazın parsiyel basıncıyla doğru orantılıdır ( $C$, sıvıda çözünen gazın derişimi; $P$, sıvı üzerindeki gazın kısmi basıncı; $k$, Henry sabiti):

$$
C=k \times P_{g a z}
$$

\section{HBO TEDAVISININ FiZYOLOJIK ETKILERi}

\section{Doku Hipoksisinde Azalma}

Normal atmosfer şartlarında ve normal solunumda hemoglobin \%97-99 oranında oksijenle doymuş halde bulunur. Bununla birlikte, bir miktar oksijen de plazmada çözünmüş olarak taşınır. HBO tedavisi ile, plazmada çözünmüş halde bulunan oksijenin miktarı artarak doku oksijenlenmesinde artış meydana gelir. ${ }^{[1-3,10,11]}$

Deniz seviyesindeki normal barometrik basınçta hava solurken, 1 litre kanda $3 \mathrm{ml}$ plazma oksijen konsantrasyonuyla, arteriyel oksijen basıncı ve doku oksijen basıncı sırasıyla $100 \mathrm{mmHg}$ ve $55 \mathrm{mmHg}$ 'dir. Bununla birlikte, solunan hava hiperbarik düzeyde olduğunda -örneğin; 3 ATA basınç altında \%100 oksijenli ortamda- çözünmüş plazma oksijen konsantrasyonu 1 litre kanda 60 ml'ye, arteriyel oksijen basıncı ve doku oksijen basınc ise sırasyyla $2000 \mathrm{mmHg}$ ve 500 mmHg'ye yükselir. ${ }^{[1-3,10-12]}$

\section{Reaktif Vazokonstriksiyon}

Hiperoksinin etkisiyle kontraksiyona uğramış küçük vasküler yapılarda, var olan plazmada çözünmüş yüksek oksijen seviyesi ile normal doku oksijenlenmesi sürdürülürken, doku ödemi azaltılmış olur. Kompartman sendromunda ve ezilme yaralanmalarında görülen posttravmatik doku ödemi düzeylerinde artış, vazokonstriksiyon yardımı ile önemli ölçüde azaltılabiliı. ${ }^{[1-3,10-12]}$

\section{Iyileştirme Etkisi}

HBO tedavisi hipoksik dokuda büyüme faktörlerinin sentezini arttırırken, anjiyogenez aracılığı ile mikrovasküler ağların genişlemesine katkıda bulunur, böylece sorunlu ve kronik yaralarda iyileşme potansiyelini de arttırır. ${ }^{[12]}$ HBO tedavisi aynı zamanda osteoklastların ve osteoblastların aktivitesini arttırır, fibroblast proliferasyonunu ve kollajen sentezini uyarır. ${ }^{[1-3,10,11]}$

\section{Oksijen Basıncı Artışı}

Zehirli gazların (karbon monoksit, hidrojen sülfür, siyanür ve karbon tetraklorür) vücuttan uzaklaştırılmasına yardımcı olur. Alveol havasında yüksek konsantrasyonlarda oksijen bulunması halinde, zehirli gazlar hemoglobinden daha hızlı şekilde ayrılmaktadır. ${ }^{[3,10,13]}$

\section{Antibakteriyel Etki}

HBO tedavisi, anaerob organizmaların spor ve endotoksin oluşturma yeteneğini azaltır. Lokal mikro-dolaşımı iyileştirerek, yüksek lökosit fonksiyonu ile mikroorganizmaların fagositozunu arttırır, makrofaj aktivasyonunu sağlar, bakterilerin yok edilmesine neden olan anti-inflamatuvar etkiye katkıda bulunur. ${ }^{[1-3,10-12]}$

\section{Basınç Etkisi}

Gaz embolisi ve dekompresyon hastalı̆̆ında, gaz kabarcıklarının hacmini azaltarak tedavi sağlar. ${ }^{[1-3,14]}$

\section{HBO TEDAVISININ ETKILERI}

- İmmün stimülasyon

- Bakterisidal etki

- Doku hipoksisinde azalma

- Anjiyogenezis

- Fibroblast proliferasyonu

- Kollajen sentez artışı

- Zararlı gazların toksisitesinin baskılanması

- Doku ödeminde azalma 


\section{HBO TEDAVISININ ENDIKASYONLARI}

UHMS ve FDA (Food and Drug Administration), HBO tedavisinin güvenli kullanımı için 14 endikasyon bildirmiştir. ${ }^{[1,3,6,7,15]}$ Ülkemizde ise Sağlık Bakanlığı tarafından 2001 yılında yürürlüğe konulan "Hiperbarik Oksijen Tedavisi Uygulanan Özel Sağlık Kuruluşları Hakkında Yönetmelik"te yer alan; UHMS ve ECHM (Europan Committee of Hyperbaric Medicine) derneklerinin bildirdiği endikasyon dahilindeki hastalıklar dikkate alınarak HBO tedavisi uygulanmaktadır. ${ }^{[16]}$

\section{Endikasyonlar}

1. Dekompresyon hastalığı

2. Hava veya gaz embolisi

3. Karbonmonoksit ve siyanid zehirlenmesi, akut duman inhalasyonu

4. Gazlı gangren

5. Yumuşak dokunun nekrotizan enfeksiyonları

6. Ezici (Crush) yaralanmalar, kompartman sendromu ve diğer akut travmatik iskemiler

7. Yara iyileşmesinin geciktiği durumlar (diyabetik ve non-diyabetik)

8. Kronik refrakter osteomiyelit

9. Aşırı kan kaybı

10. Radyasyon nekrozları

11. Tutması şüpheli deri flepleri ve greftleri

12. Termal yanıklar

13. Beyin absesi

14. Anoksik ensefalopati

15. Ani işitme kaybı

16. Retinal arter oklüzyonu

17. Kafa kemikleri, sternum ve vertebraların akut osteomiyelitleri

\section{HBO TEDAVISININ KONTRENDIKASYONLARI}

\section{Kesin Kontrendikasyon}

- Tedavi edilmemiş pnömotoraks

- Bazı ilaçların HBO tedavisi sırasında toksik olduğu gözlenmiştir ${ }^{[17]}$

o Kemoterapötik ilaçlar; Doksorubisin, Sisplatin, Bleomisin

o Antibakteriyel ilaçlar; Mafenid asetat

o Alkolizm tedavisi; Disülfiram

\section{Göreceli Kontrendikasyon}

- Üst solunum yolu enfeksiyonları

- Akciğer grafisinde asemptomatik pulmoner lezyonun varlığı

- Karbondioksit retansiyonu ile oluşan amfizem

- Geçirilmiş göğüs ameliyatı veya kulak ameliyatı öyküsünün bulunması

- Bilinç kaybı, bayılma nöbetleri

- Malignite varlığı

- Gebelik

- Optik nörit

- Konjestif kalp yetmezliği

- Kontrol edilemeyen hipertermi, hipotermi

- Klostrofobi

- Kalp pili varlı̆̆ı

\section{HBO TEDAVISININ YAN ETKILERI}

- Orta kulak/akciğer/paranasal sinus/dental barotravması

- Dekompresyon hastalığı

- Oksijen toksisitesi

- Kusma

- Katarakt

- Ilerleyici miyopi

- Yorgunluk

- Klostrofobi

- Hipoglisemi

- Trombositopeni

- Solunum yetmezliği

- Baş ağrısı

- Kıllanma artışı

\section{HBO TEDAVISININ ORTOPEDI VE TRAVMATOLOJIDEKI UYGULAMALARI}

UHMS ve FDA tarafindan kabul edilen 14 endikasyon arasından, hava embolisi ve dekompresyon hastalığının tedavisi diğerlerine göre çok daha iyi tanımlanmıştır ve tedavi sonuçlarına yönelik daha güçlü kanıtlar mevcuttur. ${ }^{[1,3,6,7,10]} \mathrm{HBO}$ tedavisinin ortopedi ve travmatoloji alanındaki çeşitli hastalıklarda başarılı uygulama sonuçları vardır. Diğer yandan bazı endikasyonlarda ise, mevcut kanıtların zayıflığı ve randomize kontrollü çalışmaların eksikliği nedeniyle, HBO tedavisinin etkinliğini belirlemek için daha fazla araştırma gerekmektedir. 


\section{Nekrozitan Yumuşak Doku Enfeksiyonları (Klostridium Dışı), Gazlı Gangren (Klostridial)}

Klostridium dışı nekrotizan yumuşak doku enfeksiyonları, ilerleyici, çoklu bakteriyel enfeksiyonlar sonucu gelişen subkutanöz ve kutanöz tabakaların tutulumuna ek olarak, derin fasyayı da içine alan enfeksiyonlardır; genellikle kronik hastalığı bulunan kişilerde görülür. HBO tedavisi, bu gibi durumlarda yardımcı bir tedavi aracı olarak kullanılabilmektedir. $[1,3,6,18]$

Enfeksiyona karşı yeterli konak yanıtı verilemediğinden, anaerobik enfeksiyonlar çoğunlukla hipoksik bölgelerde gelişir. HBO tedavisinin amacı, iskeminin hafifletilmesi ve enfeksiyona karşı konak cevabının iyileştirilmesi olarak düşünülmektedir. ${ }^{[18,19]}$ Bazı mikroorganizmalar ise HBO tedavisi yoluyla elde edilen yüksek oksijen basıncına oldukça duyarlıdır. ${ }^{[6]}$ Artan doku oksijen gerilimi, nekrotizan selülit, ilerleyici dermal gangren, anaerobik streptokokkal miyozit, krepitan anaerobik selülit ve nekrotizan fasit durumlarında; HBO tedavisi bakterilerin lökositler tarafından öldürülmesini arttırır, anaerobik organizmanın çoğalmasını engeller ve oksidasyon redüksiyon potansiyelini arttırır. ${ }^{[1]}$

Nekrotizan fasiitisde yardımc tedavi olarak HBO üzerine yapılan bir Cochrane sistematik incelemesinde, HBO tedavisinin etkinliğini tam olarak destekleyecek veya çürütecek ilgili klinik bulguya ulaşılamamıştır. ${ }^{[20]}$ Diğer yandan, geriye dönük bir kohort araştırmasında ise HBO tedavisinin nekrotizan yumuşak doku enfeksiyonunda ekstremite kurtarma ve sağkalımın oranlarını arttırdığı tespit edilmiştir. ${ }^{[18]}$

Gazlı gangren (klostridial miyonekroz) oluşumundan \%80-95 oranında sorumlu etken Clostridium perfringens'tir. Azalan sıklıkla, C.novyi ve C.septicum da spontan travmatik olmayan gazlı gangrenlerden sorumludur. Klostridial miyonekrozda, dokuların akut ilerleyici enfeksiyonu sonrası ödem, doku tahribatı ve toksemi gelişir. ${ }^{[19]}$

Gerek nekrozitan yumuşak doku enfeksiyonlarında gerekse gazlı gangrende HBO tedavisi, bakteri ve toksinlerin azaltılmasına yardımcı olmak amaçı doku debridmanına ek olarak kullanılmaktadır.

Gazlı gangren için; ilk 24 saatte 3 ATA'da, \%100 oksijen ile günde üç kez, 90 dakikalık tedavi şekli uygulanmaktadır. illk tedavilerin ardından, 4-5 gün süresince günde iki kez şeklinde tedavi sürdürülmektedir. ${ }^{[7,15]}$

Klostridium dışı nekrotizan yumuşak doku enfeksiyonları için ise; günde iki kez, 2,0-2,5 ATA'da, $\% 100$ oksijen ve semptomlar azaldığında günde bir seansa düşürülerek, toplamda 30 seans uygulanmaktadır. ${ }^{[7,15]}$

\section{Akut Travmatik İskemi, Ezilme Yaralanması, Kompartman Sendromu}

Akut travmatik iskemi, dolaşımı tehlikeye atan bir durumda ortaya çıkmakta ve ekstremitede nekroz veya ampütasyon riski oluşturabildiği gibi ikincil komplikasyonlar ile enfeksiyon, iyileşmeyen yaralar ve kırıkta kaynamama gibi durumlara da yol açabilmektedir. ${ }^{[1]}$ HBO tedavisi uygulamalarının, bu yaralanmalarla ilişkili morbidite ve mortaliteyi önemli ölçüde azalttığı gösterilmiştir. Yüksek atmosferik basınç altında \%100 oksijen solunumu ile sağlanan yüksek oksijen gradiyenti, büyük proksimal kan damarlarının tıkanması nedeniyle meydana gelebilecek sınırlı kan akışı süresince, dokulardaki hipoksik zonda parsiyel oksijen basıncını yükseltir ve bu şekilde dokuların canlılığının devamına imkan sağlar. ${ }^{[6]}$

Ezilme yaralanmalarında; eklemler, kemikler, tendonlar, kaslar ve cilt gibi birden fazla yapıda doku travması oluşabilmektedir. HBO tedavisi, anjiyogenezi kolaylaştıran kollajen ve fibroblast sentezini uyarmasının yanı sıra plazma oksijenasyonunun artışı yoluyla doku oksijen basıncını yeniden düzenlemek için kullanılmaktadır. ${ }^{[21]}$ Ezilme yaralanmalarında yüksek arteriyel oksijen basıncı, doku oksijenasyonunu iyileştirir, vazokonstriksiyon ile travmatik ödemi ve kompartman sendromu olasılığını azaltır. ${ }^{[6,21]}$ Bununla birlikte, ekstremitelerde travma sonrası oluşan iskemilerde, dokularda yetersiz parsiyel oksijen basıncı nedeniyle anaerobik metabolizma devreye girer. Temel hücresel faaliyetler için gerekli olan enerji, iskemi durumunda glikolizle elde edilen az miktardaki enerji ile karşılanamamakta ve hücre ölümü gerçekleşmektedir. HBO tedavisi ile aerobik metabolizma uyarılarak temel hücresel faaliyetler için gerekli olan enerji sağlanır. ${ }^{[3,21]}$

Kompartman sendromu, fasyalar arası veya kemik faysa arası kapalı bir anatomik boşlukta interstisyel doku basıncının artışı sonucu dolaşımın bozulması ve içerisindeki yapıların nekrozu ile karakterizedir. ${ }^{[22]}$ Klinik tablo; dokulardaki basınç artışı, ödem veya hemoraji nedeni ile kompartman alanının azalması ya da kompartman içi volüm artışına bağlı olarak gelişir. ${ }^{[22]}$

HBO tedavisi, kompartman sendromlu hastalarda, doku hipoksisi nedeniyle bozulan damar geçirgenliğini düzenleyerek ödemi azaltacağı ve kompartman içi basıncı düşüreceği düşüncesiyle önerilmektedir. ${ }^{[3,4,23]}$ Kompartman sendromu gibi durumlarda hiperoksi uygulaması ile, vazokonstriksiyonun bir sonucu olarak iskemi ve ödem döngüsü dokuya aktarılan oksijen akışı bozulmadan çözülür. ${ }^{[23]}$ HBO tedavisi sonucunda, plazmada çözünen oksijen miktarı arttırılarak doku hipoksisi engellenir, fonksiyon kaybı azaltılır. ${ }^{[1,2,3,4]}$ 
Kompartman sendromunun da aralarında bulunduğu akut travmatik iskemilerde HBO tedavisi; ilk 4-6 saat içinde başlatılması, ilk iki gün 8 saatte bir, izleyen günlerde ise günde bir kez olmak üzere, 90 dakikalık, 2,0 ATA'da, \%100 oksijen solutularak uygulanmaktadır. ${ }^{[4,7,15]}$

\section{Problemli Yaralar}

HBO tedavisi, bakterilere karşı lökositlerin öldürme fonksiyonlarını güçlendirerek konağın bağışıklık yanıtını arttırır. ${ }^{[1,3,7,15]}$ Anaeroblara karşı sitotoksiktir ve bu nedenle çeşitli nekrotizan enfeksiyonlarda morbidite ve mortaliteyi azaltır. HBO tedavisi, aminoglikozidlerin hücre duvarı boyunca taşınmasını aktive ederek bu antibiyotiklerin etkinliğini arttırır. ${ }^{[1,3,7,15]}$ Aynı zamanda, arteriyel vazokonstriksiyon ile lokal doku ödemini azaltırken lokal doku oksijen basıncını daha yüksek tutar; azalmış ödem ile dokuya daha iyi oksijen penetrasyonu ve besin sağlanır. ${ }^{[5]}$

HBO tedavisi; diyabetik ve iskemik ayak ülserleri, sorunlu ampütasyon güdük yerleri, iyileşmeyen travmatik yaralar ve vasküler yetersizlik ülserleri ve radyasyon sonrası ülserler gibi problemli yaraların tedavisinde sıklıkla kullanılmaktadır. ${ }^{[1,5,24]}$ Bu gibi yaralarda doku hipoksisi bulunur ve oksijen parsiyel basıncı $20 \mathrm{mmHg}$ 'nın altında ve bu nedenle yara enfeksiyona daha yatkındır. ${ }^{[1]} \mathrm{HBO}$ tedavisi sonucu oksijen geriliminin yükselmesi, hem lökositlerin bakterisit aktivitesini güçlendirmesi hem de neovaskülarizasyon için gerekli fibroblast-kollajen desteğini sağlanması ile, yara iyileşmesini üzerinde güçlü etkilere sahiptir. ${ }^{[24,25]}$ HBO tedavisi sonucu, doku hasar onarımı için çok önemli olan kök hücrelerin mobilizasyonunun sağlandığı ve fibroblast oluşumunu arttığı in vitro deneylerle gösterilmiştir. ${ }^{[5,26]}$

Çeşitli çalışmalarda, HBO tedavisi ile daha düşük ekstremite ampütasyon sıklıklığının olabileceği gösterilmiştir. ${ }^{[27]}$ Diyabetik ayak ülserli 100 hastayı kapsayan ve çeşitli tedavilere cevap veremeyen randomize kontrollü bir çalışmada, HBO tedavisi kullanılarak anlamlı derecede yüksek yara iyileşmesi elde edilmiştir. ${ }^{[28]} \mathrm{HBO}$ tedavisinin etkinliği, yara iyileşmesi ve yara boyutunun azaltılmasını gösteren diğer benzer randomize kontrollü çalışmalar tarafından da desteklenmiştir. ${ }^{[29]}$

Problemli yaralarda uygulama; 2,0-2,5 ATA'da, \%100 oksijen ile günde bir kez, 90-220 dakika süresince, ortalama 30 seans şeklindedir. ${ }^{[7,15,24,29]}$

Lokal HBO tedavisi ise, aşırı oksijenasyonun sistemik yan etkilerini en aza indirgemek için doğrudan yara yüzeyine oksijen sağlamak için kullanılmaktadır. Lokal HBO tedavisi doğrudan yara yüzeyine oksijen sağladığı için, hastanın açık bir yarası olmalıdır. ${ }^{[5]}$ Özellikle kötü vaskülarize dokularda daha etkili olabilmektedir.
Lokal HBO tedavi uygulaması; 1,03 ATA'da, haftada 4 gün, 90 dakika süresince $\% 100$ oksijen şeklindedir. [5]

\section{Sorunlu Deri Greftleri ve Flepler}

HBO tedavisinin, ameliyat sonrası tehlikeye giren deri greft ve fleplerinin canlılığını devam ettirmede iyileştirici etkisi gösterilmiştir. ${ }^{[7,15]}$ Birçok çalışmada, düşük perfüzyon veya hipoksi sonucu bozulmuş dokularda aralıklı HBO tedavisi ile, tek başına ameliyat sonrası cerrahi bakıma kıyasla cilt greft ve fleplerinin sağkalımında artma tespit edilmiştir. ${ }^{[1,6,30,31]}$ HBO tedavisi ile, cilt flep veya greftlerinin canlılığı devam ettirilirken, enfeksiyon riski azalır, vasküler yapıların vazokonstriksiyonu ile ödem azalır, benzer şekilde reimplantasyon cerrahisi sonrası iskemi-reperfüzyona bağlı hasar en aza indirilir. Doku oksijen geriliminin artması, anjiyogenezi ve kollajen sentezini uyarırken, lökosit fonksiyonunun artışını sağlar. ${ }^{[5,21,26]}$

HBO tedavi uygulaması; 2,0-2,5 ATA'da, 120 dakika boyunca, $\% 100$ oksijen tedavisinin 20 gün boyunca, günde iki kez uygulanması şeklindedir. ${ }^{[7,15,31]}$

\section{Refrakter Osteomiyelit}

Kemiğin bakteriyel enfeksiyonu olan osteomiyelit için standart tedavi, antibiyotik profilaksisi ve cerrahi debridmandır. ${ }^{[32]}$ HBO tedavisi, osteomiyelit olgularında debridman ve antibiyotiklere ek olarak seçilmiş olgularda yardımcı tedavi yöntemi olarak önerilmektedir. ${ }^{[7,15]}$

HBO tedavisi, kemik ve dokulardaki oksijen basıncının hipoksi durumdan normal veya hiperoksi seviyelerine periyodik olarak yükselmesini sağlar. Enfeksiyon alanındaki oksijen geriliminin artması, lökosit ve osteoklast fonksiyonu iyileştirir ve mikroorganizmaların antibiyotiklere duyarlılığını arttııır. ${ }^{[1,6]}$ Diğer yandan, doku oksijen basıncını arttırarak kollajen sentezini aktive eder ve anjiyogenezi uyarır. HBO tedavisi sonucu oluşan serbest oksijen radikalleri aracılığı ile bakteriostatik ve bakterisitik etki gösterir. ${ }^{[1-3,6]}$

Normal ortam koşullarında kemikteki oksijen basınc yaklaşık 45 mmHg'dir. Kronik osteomiyelitli kemikte, oksijen geriliminde $\% 50$ azalma olduğu bildirilmiştir. ${ }^{[33]}$ Yeni vasküler oluşumunun aktivitesini sağlamak için ise $30-40 \mathrm{mmHg}$ oksijen gerilmeleri gerekir. ${ }^{[34,35]}$ HBO tedavisinin enfekte kemikteki yüksek oksijen gerilimini düzelttiği ve hipoksik dokuda anaerobik organizmanın büyümesini engellediği bilinmektedir. ${ }^{\left[{ }^{[6]}\right.}$ Yapılan deneysel çalışmalarda, HBO tedavisi ile enfekte kemikteki oksijen basıncının normal sağlıklı kemikteki oksijen basıncına eşit hatta daha yüksek bir değere eriştiği tespit edilmiştir. ${ }^{[34,35]}$ 
HBO tedavisinin uygulanması; antibiyotiklere ve debridmana ek olarak, 2,0-2,5 ATA'da, \%100 oksijen ile günlük 90-120 dakika süresince, ortalama 40 seans şeklindedir. ${ }^{[7,15]}$

\section{Osteonekroz}

Osteonekroz, travma, steroid kullanımı, koagülasyon bozuklukları, alkol, radyoterapi, antirezorptif ilaç kullanımı gibi çeşitli etmenlere bağlı olarak intramedüller basınç artışı, venöz staz, intra-osseöz mikro-dolaşımın bozulmasına bağlı olarak kemikte gelişen iskemi, hipoksi ve nekroz halidir. ${ }^{[37]}$ Sıklıkla femur başı olmak üzere; humerus başı, lunatum, ayak kemikleri, kosta ve temporal kemikte görülebilmektedir. ${ }^{[37]}$

Femur başı osteonekroz olgularının doğal seyrini değiştirebilmek için birçok tedavi yöntemi tanımlanmıştır. Bunların içinde; kor dekompresyon, vaskülarize olan veya olmayan kemik greftleme, osteotomiler ve artroplasti gibi çeşitli cerrahi seçeneklerin yanı sıra, elektrik stimülasyonu, farmakolojik tedaviler ve HBO tedavisi gibi cerrahi olmayan girişimler de bulunmaktadır.

Osteonekrozda HBO tedavisinin etkinliğini değerlendiren çalışmalar umut verici sonuçlar bildirmiş olmakla birlikte, çalışmaların çoğunluğu küçük ölçekli ve metodolojik açıdan zayıf olarak görülmektedir. ${ }^{[38]}$ HBO tedavisinin çoğunlukla Steinberg I veya II olgularındaki sonuçları iyileştirebileceği bildirilmektedir. ${ }^{[38]}$

Reis ve arkadaşları, Steinberg Evre I femur başı avasküler nekrozlu hasta çalışmalarında, HBO tedavisi gören hastaların \%81'inde, tedavi edilmeyen gruba kıyasla manyetik rezonans (MR) görüntülemede normale dönüş belirtileri olduğunu bildirmişlerdir. ${ }^{[39]}$ Olası mekanizma, etkilenen kemiğin oksijenasyonu ile kemik dokuyu eski durumuna getiren mikro-sirkülasyon olayını geri getirmesi olarak düşünülmektedir. Diğer yandan, HBO tedavisinin ölü kemiğin rezorbe edilmesi ve canlı kemik ile yer değiştirme sürecini aktive ettiği de bildirilmektedir. ${ }^{[38,39]}$

Camporesi ve arkadaşları, idiyopatik tek taraflı femur başı avasküler nekrozu geçiren 20 hastanın çift kör ve ileriye dönük randomize kontrollü çalışmasında, HBO tedavi grubunun, kontrol grubuna kıyasla hem ağrı hem de eklem hareket açıklığı açısından istatistiksel olarak anlamlı bir iyileşme gösterdiğini tespit etmişlerdir. ${ }^{[40]}$

Koren ve arkadaşları, HBO tedavi öncesi ve sonrası MR ile karşılaştırdıkları Steinberg Evre I ve II femur başı osteonekrozlu 74 eklemin 65 'inde lezyon boyutunda azalma olduğunu bildirmişlerdir. ${ }^{[41]}$ Ortalama 11 yıllık takip sonunda, artroplasti uygulanan dört hasta dışında diğer hastalarda canlılığının devam ettiğini ve fonksiyonel sonuçların iyi olduğunu bildirmişlerdir. ${ }^{[41]}$
Tekrarlanan günlük HBO tedavisi ile, birincil etki olarak, kemik nekrozu olan bölgede ve çevre dokularda oksijen konsantrasyonu artmakta, iskemi sonucu ortaya çıkan doku nekrozu engellenmektedir. ${ }^{[38]} \mathrm{HBO}$ tedavisi sonucu, oksijene bağımlı vazokonstriksiyon ile erken dönemde nekrotik bölgedeki ödem doğrudan azalırken, venöz drenaj düzenlenerek intra-osseöz basıncın düşmesi ve doku perfüzyonunun artması sağlanmaktadır. ${ }^{[42]}$ HBO tedavisinin diğer bir etki mekanizması ise; ikincil olarak osteoblastik ve osteoklastik aktivitenin düzenlenmesi, makrofaj ve fibroblast işlevinin iyileştirilmesi, anjiyogenezin ve osteojenezin arttırılmasıdır. ${ }^{[6,42]}$

Osteonekrozda uygulanan HBO tedavisi; 2,0-2,5 ATA'da, 90 dakika boyunca \%100 oksijenin haftada beş kez olmak üzere, ortalama $20-100$ seans şeklindedir. ${ }^{[7,15,38]}$

\section{Spor Yaralanmaları}

Rekabet sporunun artan yoğunluğunun bir sonucu olarak, spor yaralanmalarının sıklığı artmaktadır. Yumuşak dokuyu etkileyen yaralanmalar yaygındır ve hafif çürüklerden bağ, tendon ve kaslara kadar ciddi hasar verebilecek durumlar gelişebilmektedir. Bu gibi yaralanmaların nedeni; aşırı kullanım, tekrarlayan zorlanmalar ile travmatik yaralanmalar şeklinde olabilmektedir. Buna ek ve alışılagelmiş olmayan egzersizin bir sonucu olarak da, ciddi ağrı ve şişlikten hafif kas ağrısına kadar, kapalı yumuşak doku yaralanmaları gelişebilmektedir. ${ }^{[10]}$

HBO tedavisi, inflamasyonu ve lokal doku hipoksisini azaltarak iyileşme sürecini hızlandırabilmesi nedeniyle spor yaralanmalarında ilgi çekmektedir. Ancak, bu alanda HBO kullanımını destekleyen kesin bilimsel kanıtlar bulunmamaktadır.

Bu alandaki bir araştırmada, bazı çalışmalarda HBO kullanımında potansiyel bir yarar tespit edilirken, ${ }^{[43,44]}$ bazı çalışmalarda ise önemli bir farklılık olmadığı bildirilmiştir. ${ }^{[45-47]}$

Borromeo ve arkadaşları, HBO tedavisinin ayak bileği burkulmalarını takiben rehabilitasyon sürecine etkilerini belirlemeyi amaçladıkları randomize, çift kör çaIş̧malarında; ödem, ağrı, pasif ve aktif eklem hareket açıklığı veya iyileşme süresi yönünden kontrol grubu ile kıyaslandığında, HBO tedavisi açısından anlamlı farklılık bulunamamıştır. ${ }^{[44]}$

Germain ve arkadaşlarının, HBO tedavisinin egzersize bağlı kas hasarının iyileşmesini hızlandırıp hızlandırmadığını belirlemeyi amaçladıkları randomize çalışmalarında, HBO tedavi grubu ile kontrol grubu arasında anlamlı fark bulunamamıştır. ${ }^{[45]}$ 
Kas ağrısı ve kapalı yumuşak doku hasarı tedavisinde $\mathrm{HBO}$ tedavisi uygulaması üzerine yeterli randomize kontrollü çalışmaların olmaması, HBO tedavisinin etkinliğini değerlendirmeyi zorlaştırmaktadır. HBO tedavisinin etkililiğini saptamak için; daha büyük örnekler içeren, optimal basınç, sıklık ve tedavi sürelerini göz önüne alınan çalışmalar gereklidir. ${ }^{[10]}$

Yumuşak doku yaralanmalarında uygulanan HBO tedavi yöntemi; 1,5-3 ATA'da, \%100 oksijenin, 30-60 dakika süresince uygulanması şeklindedir. ${ }^{[7,15]}$

\section{Kırık İyileşmesi}

Kemik kırıklarında stabilitenin sağlanması ve kaynamanın elde edilebilmesine yönelik birtakım tedavi yaklaşımları benimsenmiştir. Kullanılan yöntemler arasında; içten veya dıştan çeşitli tespit tipleri, kemik grefti, elektrik stimülasyonu ve ekstrakorporeal şok dalga tedavisi gibi yöntemler sayılabilir. ${ }^{[48,49]} \mathrm{HBO}$ tedavisi kemik kırıklarının tedavisinde kullanılmıştır, ancak bu alandaki olumlu kanıtlar sınırlıdır. ${ }^{[2,50]}$

Deneysel çalışmalarda HBO tedavisinin potansiyel yararlar sağladığına ilişkin bulgulara rağmen, insanlardaki kemik kırıklarının iyileşmesi, gecikmiş kırık iyileşmesi veya kaynamamaya ilişkin tedavideki olumlu etkisi tam olarak gösterilememiştir. ${ }^{[50,51]}$ Kemik kırığı, kaynama gecikmesi veya kaynamama durumları için HBO tedavisinin kullanımını destekleyen veya reddeden yeterli sayıda randomize kontrollü çalışma bulunmamaktadır. ${ }^{[2]}$

Uygulanan HBO tedavi yöntemi; 1,5-3 ATA'da, \%100 oksijenin, 30-60 dakika süresince uygulanması şeklindedir. ${ }^{[7,15]}$

\section{Sinir İyileşmesi}

HBO tedavisinin etkisi, dolaşımda çözünmüş oksijenden zengin plazmanın sağlanmasıdır. ${ }^{[52-54]} \mathrm{HBO}$ tedavisi, dolaşım ile çevreleyen dokular arasında geçici olarak artmış bir diffüzyona neden olan, çözünmüş oksijen bakımından hipersatüre bir plazmaya yol açar. ${ }^{[52]}$ HBO tedavisinin akut ve kronik spinal kord yaralanmalarında yararlılığına ilişkin bazı çalışmalar bildirilmiştir. ${ }^{[54]}$

HBO tedavisi, serebral iskemi ve beyin travmasında nöroprotektif etkiye sahiptir. ${ }^{[55]}$ Hiperbarik oksijen tedavisinin patolojik koşullarda oksidatif stresi azalttığı, [53] deneysel modellerde spinal kord yaralanması sonrası oluşan ödem ve hipoksik durumu iyileştirici etkisi olduğu gösterilmiştir. ${ }^{[53,56]}$

Topuz ve arkadaşları, deneysel akut spinal kord yaralanmalarında hipotermi ve HBO tedavi kombinasyonunun, lipid peroksidasyonunu önleyerek ve serbest radikal seviyelerini düşürerek omuriliği ikincil hasarlardan koruduğu sonucuna varmışlardır. ${ }^{[53]}$ Cristante ve arkadaşları, sıçanlar üzerinde gerçekleştirdikleri deneysel çalışmalarında, spinal kord yaralanmasından hemen sonra uygulanan HBO tedavisinin, omurilik lezyonlarının fonksiyonel olarak iyileşmesinde yararlı olduğunu göstermişlerdir. ${ }^{[52]}$

Bununla birlikte, HBO tedavisinin spinal kord yaralanmalarında kullanışlılığına ilişkin olarak birçok belirsiz noktanın kalmış olduğu ve bazı çalışmalarda iyileşme oranının geleneksel yaklaşımlarla elde edilenlerden hiçbir fark göstermediği de belirtilmektedir. ${ }^{[54]}$ Ayrıca, tedavinin insanlarda da uygulanabilirliği göstermek için; tedavinin yoğunluğu, dozu, süresi ve periyodik değişiminin diğer çalışmalarda test edilmesi gerekir. ${ }^{[52,53]}$

HBO tedavisinin periferik sinir yaralanmalarında aksonal rejenerasyonu arttırdığı ve benzer şekilde, sinir greft iyileşmesini hızlandırdığı belirtilmektedir. ${ }^{[57]}$ Oroğlu ve arkadaşları, deneysel çalışmalarında, HBO tedavisinin gergin durumdaki sinirin iyileşmesini aktive ettiğini tespit etmişlerdir. ${ }^{[58]} \mathrm{HBO}$ tedavisinin, ezilme yaralanmasında periferik sinir iyileşmesini hızlandırabileceği bildirilmektedir. ${ }^{[57]}$

HBO tedavisi, sinir iyileşmesi ve buna ilişkin süreçlerin geliştirilmesine yönelik yardımcı tedavi yöntemlerinden biri olarak öneri niteliğindedir ve çalışmaların çoğunluğu deneysel hayvan modelleridir. HBO tedavisinin spinal kord yaralanmalarında ve periferik sinir yaralanmalarındaki potansiyel yararlarının belirlenmesine yönelik, kanıt değeri yüksek çalışmalara ihtiyaç vardır.

Uygulanan HBO tedavi yöntemi; 2,0-2,5 ATA'da, 90 dakika süresince, günde iki kez, $\% 100$ oksijenin ortalama 7-10 gün uygulanması şeklindedir. ${ }^{[54,57]}$

\section{SONUÇ}

HBO tedavisinin, yan etkilerinin belirlenmesi, kontrendikasyonlarının tespit edilmesi ve gelişebilecek sorunlara uygun güvenlik prosedürlerinin uygulanabilmesi sonucunda, güvenli ve etkin yardımcı bir tedavi yöntemi olacağı görülmektedir.

Günümüzde $\mathrm{HBO}$ tedavisinin etkilerinin daha iyi anlaşılması ile, ortopedi ve travmatoloji alanındaki; diyabetik yaralar, problemli yaralar, nekrotizan yumuşak doku enfeksiyonları, kronik osteomiyelit, sorunlu deri flep ve greftleri, bazı akut iskemik durumlar, gazlı gangren gibi patolojiler $\mathrm{HBO}$ tedavisinin yaygın endikasyon alanına girmiştir ve $\mathrm{HBO}$ etkin bir tedavi yöntemi olarak kullanılmaktadır. Diğer yandan, spor yaralanmaları, kapalı yumuşak doku yaralanmaları, kırık iyileşmesi, osteonekroz, omurilik yaralanmaları, 
periferik sinir yaralanmaları gibi patolojilerde ise; $\mathrm{HBO}$ tedavisi sonuçlarına ilişkin olumlu raporlar olmakla birlikte, etkinliğine yönelik kanıt değeri daha yüksek çalışmalara ihtiyaç duyulmaktadır.

\section{KAYNAKLAR}

1. Sahni $T$, Singh $P$, John MJ. Hyperbaric oxygen therapy: current trends and applications. J Assoc Physicians India 2003;51:280-4.

2. Greensmith EJ. Hyperbaric oxygen therapy in extremity trauma. J Am Acad Orthop Surg 2004:12(6);376-84.

3. Topal T, Korkmaz A. Hiperbarik Oksijen Tedavisi. Turkiye Klinikleri J Med Sci 2008;28(2):206-16.

4. Aydın F, Aktaş Ş, Olgaç V, Mezdeği A, Karamülsel S. Deneysel kompartman sendromunda cerrahi dekompresyonla kombine edilen hiperbarik oksijen tedavisinin etkinliği. Ulus Travma Acil Cerrahi Derg 2003;9(3):176-82.

5. Mehta Vandana, De Abhishek, Balachandran C. Hyperbaric oxygen therapy. Journal of Pakisthan Association of Dermatologists 2009;19:164-7.

6. Gupta V, Vijay S, Gupta R, Koul S. Hyperbaric oxygen therapy. JK Pract 2005;12:44-7.

7. Weaver LK, editor. Hyperbaric oxygen therapy indications, 13th ed. Durham: Undersea and Hyperbaric Medicine Society; 2014.

8. Thom SR. Hyperbaric oxygen: its mechanisms and efficiency. Plast Reconstr Surg 2011;127 Suppl 1:131S-41S. Crossref

9. Kindwall EP. The physics of diving and hyperbaric pressures. In: Kindwall EP, Whelan HT, editors. Hyperbaric Medicine Practice, 2nd ed. Flagstaff (AZ): Best Publishing; 1999. p.22-35.

10. Sanderson P, Goodwin PC. Evidence for the use of Hyperbaric Oxygen Therapy (HBOT). A Review. Manchester Metropolitan University; 2015.

11. Leach RM, Rees PJ, Wilmhurst P. Hyperbaric Oxygen Therapy. BMJ 1998;317(7166):1140-3.

12. Simsek K, Oter S, Ay H. Hyperbaric Oxygen therapy and its mechanisms of action: implication of several molecular processes along with reactive species. J Exp Integr Med 2011;1:205-6.

13. Garrrabou G, Inoriza JM, Morén C, Oliu G, Miró Ò, Marti MJ, Cardellach F. Hyperbaric oxygen therapy for carbon monoxide poisoning. Intensive Care Med 2011;37(10):17112. Crossref

14. Thom SR. Oxidative stress is fundamental to hyperbaric oxygen therapy. J Appl Physiol (1985) 2008;106(3):988-95. Crossref

15. Gesell LB. Hyperbaric Oxygen Therapy Indications, 12th ed. Durham, NC: Undersea and Hyperbaric Medical Society; 2008.

16. http://www.saglik.gov.tr/TR,10431/hiperbarik-oksijen-tedavisiuygulanan-ozel-saglik-kuruluslari-hakkinda-yonetmelik.html

17. Smith RG. An appraisal of potential drug interactions regarding hyperbaric oxygen therapy and frequently prescribed medications. Wounds 2011;23(6):147-59.

18. Wilkinson D, Doolette D. Hyperbaric oxygen treatment and survival from necrotizing soft tissue infection. Arch Surg 2004;139(12):1339-45. Crossref

19. Stevens DL. The Pathogenesis of clostridial myonecrosis. Int J Med Microbiol 2000;290(4-5):497-502. Crossref
20. Levett $\mathrm{D}$, Bennett $\mathrm{MH}$, Millar I. Adjunctive hyperbaric oxygen for necrotizing fasciitis. Cochrane Database of Syst Rev 2015;1:CD007937. Crossref

21. Zamboni WA, Roth AC, Russell RC, Graham B, Suchy H, Kucan JO. Morphological analysis of the microcirculation during reperfusion of ischaemic skeletal muscle and the effect of hyperbaric oxygen. Plast Reconstr Surg 1993;91(6):1110-23.

22. Koyuncu Ş, Ozan F, Gürbüz K. Gluteal Compartment Syndrome Secondary to Traumatic Rupture of Gluteus Maximus. J Ann Eu Med 2016;1(Suppl 1):4-7. Crossref

23. Nylander G, Lewis D, Nordstrom H, Larsson J. Reduction of postischemic oedema with hyperbaric oxygen. Plast Reconstr Surg 1985;76(4):596-603.

24. Abidia A, Laden G, Kuhan G, Johnson BF, Wilkinson AR, Renwick PM, Masson EA, McCollum PT. The role of hyperbaric oxygen therapy in ischaemic diabetic lower extremity ulcers: a double-blind randomised controlled trial. Eur J Vasc Endovasc Surg 2003;25(6):513-8. Crossref

25. Baroni G, Porro T, Faglia E, Pizzi G, Mastropasqua A, Oriani G, Pedesini G, Favales F. Hyperbaric oxygen in diabetic gangrene treatment. Diabetes Care 1987;10(1):81-6.

26. Kang TS, Gorti GK, Quan SY, Ho M, Koch RJ. Effect of hyperbaric oxygen on the growth factor profile of fibroblasts. Arch Facial Plast Surg 2004;6(1):31-5. Crossref

27. Kaya A, Aydin F, Altay T, Karapinar L, Ozturk H, Karakuzu $C$. Can major amputation rates be decreased in diabetic foot ulcers with hyperbaric oxygen therapy? Int Orthop 2009;33(2):441-6. Crossref

28. Duzgun AP, Satir HZ, Ozozan O, Saylam B, Kulah B, Coskun F. Effect of hyperbaric oxygen therapy healing of diabetic foot ulcers. J Foot Ankle Surg 2008;47(6):515-9. Crossref

29. Ma L, Li P, Shi Z, Hou T, Chen X, Du J. A prospective randomised, controlled study of hyperbaric oxygen therapy: effects on healing and oxidative stress of ulcer tissue in patients with a diabetic foot ulcer. Ostomy Wound Manage 2013;59(3):18-24.

30. Tai YJ, Birely BC, Im MJ, Hoopes JE, Manson PN. The use of hyperbaric oxygen for preservation of free flaps. Ann Plast Surg 1992;28(3):284-7.

31. Baynosa RC, Zamboni WA. The effect of hyperbaric oxygen on compromised grafts and flaps. Undersea Hyperb Med 2012;39(4):857-65.

32. Eckardt JJ, Wirganowicz PZ, Mar T. An aggressive surgical approach to the management of chronic osteomyelitis. Clin Orthop Relat Res 1994;(298):229-39.

33. Calhoun JH, Cobos JA, Mader JT. Does hyperbaric oxygen have a place in the treatment of osteomyelitis? Orthop Clin North Am 1991;22(3):467-71.

34. Mader JT, Brown GL, Guckian JC, Wells CH, Reinarz JA. A mechanism for the ameloriation by hyperbaric oxygen of experimental staphilococcal osteomyelitis in rabbits. J Infect Dis 1980;142(6):915-22.

35. Esterhai JL Jr, Clark JM, Morton HE, Smith DW, Steinbach A, Richter SD. Effect of hyperbaric oxygen on oxygen tension within the medullary canal in the rabbit tibia osteomyelitis model. J Orthop Res 1986;4(3):330-6. Crossref

36. Davis JC, Heckman JD, DeLee JC, Buckwold FJ. Chronic non-hematogenous osteomyelitis treated with adjunctive hyperbaric oxygen. J Bone Joint Surg Am 1986;68(8):1210-7.

37. Ceponis P, Keilman C, Guerry C, Freiberger JJ. Hyperbaric oxygen therapy and osteonecrosis. Oral Dis 2017;23(2):14151. Crossref 
38. Uzun G, Mutluoglu M, Ersen O, Yildiz S. Hyperbaric oxygen therapy in the treatment of osteonecrosis of the femoral head: a review of the current literature. Undersea Hyperb Med 2016;43(3):189-99.

39. Reis ND, Schwartz O, Militianu D, Ramon $Y$, Levin D, Norman D, Melamed Y, Shupak A, Goldsher D, Zinman C. Hyperbaric oxygen therapy as a treatment for stage-I avascular necrosis of the femoral head. J Bone Joint Surg Br 2003;85(3):371-5.

40. Camporesi EM, Vezzani G, Bosco G, Mangar D, Bernasek TL. Hyperbaric oxygen therapy in femoral head necrosis. J Arthroplasty 2010;25(6 Suppl):118-23. Crossref

41. Koren L, Ginesin E, Melamed Y, Norman D, Levin D, Peled E. Hyperbaric oxygen for stage I and II femoral head osteonecrosis. Orthopedics 2015;38(3):200-5. Crossref

42. Al Hadi H, Smerdon GR, Fox SW. Hyperbaric oxygen therapy suppresses osteoclast formation and bone resorption. J Orthop Res 2013;31(11):1839-44. Crossref

43. Staples JR, Clement DB, Taunton JE, McKenzie DC. Effects of hyperbaric oxygen on a human model of injury. Am J Sports Med 1999;27(5):600-5. Crossref

44. Borromeo CN, Ryan JL, Marchetto PA, Peterson R, Bove AA. Hyperbaric oxygen therapy for acute ankle sprains. Am J Sports Med 1997;24(5):619-25. Crossref

45. Germain G, DelaneyJ, Moore G, Lee P, Lacroix V, Montgomery D. Effect of hyperbaric oxygen therapy on exercise-induced muscle soreness. Undersea Hyperb Med 2003;30(2):135-45.

46. Mekjavic IB, Exner JA, Tesch PA, Eiken O. Hyperbaric oxygen therapy does not effect recovery from delayed onset of muscle soreness. Med Sci Sports Exerc 2000;32(3):558-63.

47. Babul S, Rhodes E, Taunton J, Lepawsky M. Effects of intermittent exposure to hyperbaric oxygen for the treatment of an acute soft tissue injury. Clin J Sports Med 2003;13(3):138-47.

48. Karamitros AE, Kalentzos VN, Soucacos PN. Electrical stimulation and hyperbaric oxygen therapy in the treatment of non-unions. Injury 2006;37 Suppl 1:S63-73. Crossref
49. Biedermann R, Martin A, Handle G, Auckenthaler T, Back C, Krismer M. Extracorporeal shockwaves in the treatment of nonunions. J Trauma 2003;54(5):936-42. Crossref

50. Tuncel Ş, Ozan F, Aydın F, Yıldız H, Bora OA. The effect of hyperbaric oxygen therapy on improvement of fracture in denervated rat femur. Ege Tip Dergisi 2013;52(1);20-6.

51. Wang I, Ueng SW, Yuan L, Tu Y, Lin S, Wang C, Tai CL, Wang $\mathrm{KC}$. Early administration of hyperbaric oxygen therapy on distraction osteogenesis -a quantitive study in New Zealand rabbits. J Trauma 2005;58(6):1230-5.

52. Cristante AF, Damasceno ML, Barros Filho TE, de Oliveira RP, Marcon RM, da Rocha ID. Evaluation of the effects of hyperbaric oxygen therapy for spinal cord lesion in correlation with the moment of intervention. Spinal Cord 2012;50(7):502-6. Crossref

53. Topuz K, Colak A, Cemil B, Kutlay M, Demircan MN, Simsek $\mathrm{H}$, Ipcioglu O, Kucukodaci Z, Uzun G. Combined hyperbaric oxygen and hypothermia treatment on oxidative stress parameters after spinal cord injury: an experimental study. Arch Med Res 2010;41(7):506-12. Crossref

54. Asamoto $\mathrm{S}$, Sugiyama $\mathrm{H}$, Doi H, lida M, Nagao T, Matsumoto $\mathrm{K}$. Hyperbaric oxygen (HBO) therapy for acute traumatic cervical spinal cord injury. Spinal Cord 2000;38(9):538-40.

55. Henninger $N$, Küppers-Tiedt L, Sicard KM, Günther A, Schneider D, Schwab S. Neuroprotective effect of hyperbaric oxygen therapy monitored by MR-imaging after embolic stroke in rats. Exp Neurol 2006;201(2):316-23. Crossref

56. Ishihara $H$, Kanamori $M$, Kawaguchi $Y$, Osada R, Ohmori $\mathrm{K}$, Matsui $\mathrm{H}$. Prediction of neurologic outcome in patients with spinal cord injury by using hyperbaric oxygen therapy. J Orthop Sci 2001;6(5):385-9.

57. Sanchez EC. Hyperbaric oxygenation in peripheral nerverepair and regeneration. Neurol Res 2007;29(2):184-98. Crossref

58. Oroglu B, Turker T, Aktas S, Olgac V, Alp M. Effect of hyperbaric oxygen therapy on tense repair of the peripheral nerves. Undersea Hyperb Med 2011;38(5):367-73. 